\title{
ARMENIAN DIGITAL COMMUNICATIONS IN KARABAKH WAR OF 2020: CRITICAL DISCOURSE ANALYSIS
}

\section{ANAHIT HAKOBYAN}

\section{War framing and the media}

Control over the information flow and public opinion are key issues states have been facing during wars through centuries. Governments use different persuasive tools and techniques for certain purposes: to keep the nation's spirit high, to motivate people to join the mobilization, to perceive them that victory is worth losses, etc. Bernays was one of the first scholars stressing the role of news in shaping public opinion in wartime ${ }^{1}$. Herman and Chomsky viewed the media as narrative generating tools used for the promotion of certain policy agenda ${ }^{2}$. Lasswell argued that the main purpose of propaganda is to multiply "stimuli which are best calculated to evoke the desired responses, which are likely to instigate the undesired responses"3. Browne points four types of deceptions used by the state: prewar lies, rosy promises, propaganda and myths ${ }^{4}$. Analyzing the role of TV reporting during the Gulf war, Baudrillard stresses the hyper-realistic image of the war shaped on TV screens, which skews the ongoing situation and real purposes of the war $^{5}$. Digital communication provided enhanced the role of media in state communication strategies during armed conflicts ${ }^{6}$. A new type of war emerged, called information warfare or cyber war: the role of information as a weapon became important as never, and control over cyberspaces gained as much crucial priority as the one over the offline battlefield ${ }^{7}$.

In the scope of the role of media in armed conflicts, special attention deserve the methodological approach of framing, which analyzes the way information is structured and narratives are shaped throughout media texts. Frames are defined as interpretation packages, that is, a set of central organizing ideas that give mean-

\footnotetext{
${ }_{2}^{1}$ Bernays E. Crystallising public opinion. New York, NY: IG Publishing, 1923.

${ }^{2}$ Herman E. S., Chomsky N. Manufacturing consent: The political economy of mass media. New York, NY: Pantheon Book, 2002.

${ }^{3}$ Lasswell H. D. The theory of political propaganda. American Political Science Review, 21(3), 30, 1927, pp. 627-631.

${ }^{4}$ Browne H. The War Racket_The Lies, Myths, and Propaganda That Feed the American War Machine. Nelson Current, 2004, pp. 9-10.

${ }^{5}$ Бодрийяр Ж. Войны в заливе не было, РИПОЛ классик, Москва, 2016.

${ }^{6}$ Welch D., Fox J. Justifying War Propaganda, Politics and the Modern Age. Palgrave Macmillan UK, 2012, p. 16.

${ }^{7}$ Libicki M. C. Conquest in Cyberspace - National Security and Information Warfare. Cambridge University Press, 2007, p. 34.
} 
ing to an issue ${ }^{8}$. The framing methodology has its origins in sociology (Entman) and psychology (Tversky \& Kahneman): while the former analyzes frames in texts, the latter investigates frames in individuals' minds. Framing is a process by which a communication source constructs and defines a social or political issue for its audience ${ }^{9}$. Through media framing mass media realizes the strategy of attracting an audience by propagating, persuading, advertising, or informing narratives ${ }^{10}$. According to Entman, "To frame, is to select some aspects of a perceived reality and make them more salient in a communicating text, in such a way as to promote a particular problem definition, causal interpretation, moral evaluation, and/or treatment recommendation for the item described". His approach examines not only what is presented on media, but also what is silenced. Entman's Cascading Network Activation model analyzes media framing as a part of state information policy and an object of constant and systematic state control, whereas society appears as a less significant and less consistent factor influencing mass media ${ }^{11}$. News framing, commonly employed by the media, is widely used especially during conflicts or crises situations, as through employing different kinds of frames they simplify the storylines for complex events ${ }^{12}$.

Media framing is not only linked to public perceptions but also shaping of policy agenda during armed conflicts in general ${ }^{13}$. The rise of the culture of connectivity and attention economy significantly transformed framing practices. The increased amount of information made the framing of contemporary conflicts more chaotic and less predictable. In an environment in which Internet users can simultaneously produce and consume digital content, tools of content creation and publishing and the general architecture of online platforms become another factor strongly influencing the framing of media narratives ${ }^{14}$.

\section{Nagorno-Karabakh conflict and the Armenian-Azerbaijani informa- tion warfare}

On September 27, 2020, Azerbaijan launched the largest missile attack since the ceasefire established between Armenian and Azerbaijan in 1994. The war was the largest in the history of the conflict and was characterized as a

${ }^{8}$ Guenther L., Ruhrmann, G., Bischoff, J., Penzel, T., Weber, A. Strategic Framing and Social Media Engagement: Analyzing Memes Posted by the German Identitarian Movement on Facebook. Social Media + Society, 6(1), 2020, pp. 1-13.

${ }^{9}$ Nelson, T., Oxley, Z., Clawson, R. Toward a Psychology of Framing Effects, Political Behavior, 19: 3, 1997, pp. 221-46.

${ }_{10}$ Atanesyan A. Media Framing on Armed Conflicts: Limits of Peace Journalism on the Nagorno-Karabakh Conflict, Journal of Intervention and Statebuilding, 2020, DOI: 10.1080/17502977.2020.1780018

11 Ibid.

${ }^{12}$ Norris P., Kern M., Just M. Framing Terrorism. The News Media, the Government and the Public. Routledge, 2003, p. 8.

${ }^{13}$ Evans M. Framing international conflicts: Media coverage of fighting in the Middle East, International Journal of Media and Cultural Politics, 6 (2) pp. 209-233, 2010, p. 3.

${ }^{14}$ Makhortykh M., Sydorova, M. Social media and visual framing of the conflict in Eastern Ukraine, Media, War and Conflict, 10(3), 2017, pp. 359-381. 
"fifth-generation war" with unprecedented for South Caucasus use of advanced technology and destructive weaponry ${ }^{15}$. It was also unprecedented in the scope of the primary involvement of Turkey in military actions supporting Azerbaijan. The Second Karabakh war was history changing not only for the conflict sides but also on the level of the whole region: it changed the status quo in the Karabakh conflict that had existed since the end of the First Karabakh War in 1994 and reformatted the geopolitical configuration of the South Caucasus ${ }^{16}$.

Information warfare has been an important part of the Nagorno-Karabakh conflict since 1994. After the ceasefire, Azerbaijan started offensive antiArmenian propaganda which was organized and coordinated vertically by the strategy established by state bodies and institutions. Atanesyan identifies the following purposes of Azerbaijani propaganda: development of strengthening of Azerbaijani identity; creation of a positive international image of Azerbaijan through membership in various international organizations; protection of strategic interests; use of these organizations for anti-Armenian propaganda in order to drive and create anti-Armenian sentiments in the international community ${ }^{17}$. The Armenian informational strategy was mainly reactive and lacked a strategic approach and a scientific basis. It is noteworthy that in frames of informational warfare Azerbaijan has been outsourcing foreign public relations and strategy companies $^{18}$. During the four-day war in 2016 Azerbaijani propaganda was also proactive, aiming to spread tensions among the Armenian audience through websites and social media. The Armenian side, however, managed to resist effectively against misinformation and the Azerbaijani propaganda machine ${ }^{19}$.

The informational war strategies of Armenia and Azerbaijan during the Nagorno-Karabakh War in 2020 reflect the singularities of the abovementioned communicative strategies, as well as the level of media freedom in each country. "Freedom House" rates Internet freedom in Armenia as free ${ }^{20}$. In order to decrease the risks of the open Internet, the Armenian side, however, had to es-

15 Kocharyan S. This is 5th generation warfare, says Armenian military expert. URL: https://armenpress.am/eng/news/1029560.html(27.04.2021).

Kopalyan N. War, Nothing But War: The Virtue of Brute Force and the Shortcomings of Diplomacy. URL: https://www.evnreport.com/spotlight-karabakh/war-nothing-but-war-the-virtue-ofbrute-force-and-the-shortcomings-of-diplomacy (27.04.2021).

${ }^{16}$ Iskandaryan A. The second Karabakh war, or the first postpost-soviet war, Caucasus Instiute, Vienna, 2020. Retrived from: https://www.institutfuersicherheit.at/wp-content/uploads/2020/12/ ISP-Working-Paper-Alexander-ISKANDARYAN-The-Second-Karabakh-War-or-the-First-PostPost-Soviet-War.pdf (27.04.2021).

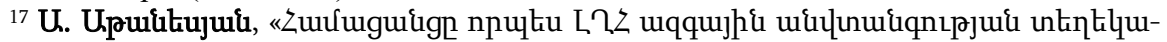

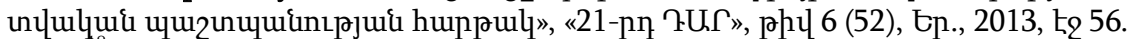

${ }_{18}$ Gulesserian L., Phillips D. L. The media war by Azerbaijan and Turkey against Armenia and Nagorno Karabakh. URL: http://humanrightscolumbia.org/news/media-war-azerbaijan-andturkey-against-armenia-and-nagorno-karabakh?fbclid=IwAR0RHO-1x4DSMboGyetunD3Mm5Z _NffFvXUVvukxTB3oLOdrpBIE4uAbonk (27.04.2021).

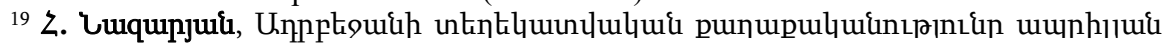

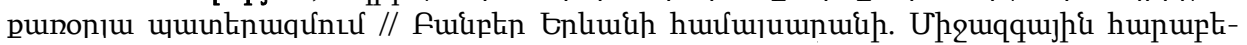

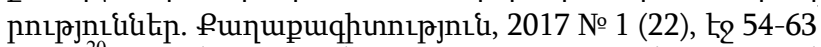

20 Freedom on the net 2020. Armenia. URL: https://freedomhouse.org/country/ armenia/freedom-net/2020_ 
tablish some media restrictions. On the $4^{\text {th }}$ day of the war, TikTok was banned after lots of citizens and organizations, including state body representatives, constantly urged users not to publish videos containing sensitive military information $^{21}$. Population lists "election.am" and "e-register.am", as well as websites with "tr." and "az." domains were blocked as well. The National Security Service of the Republic of Armenia announced that they will pursue the perpetrators of spreading false news, provocateurs, provoking panic in the society ${ }^{22}$. Fines were applied for any content including war-related information contradicting official announcements, criticizing the actions of military and political authorities, or doubting the effectiveness of their actions or defense capacity of the state. As of November 6, 309 such cases were detected, for 72 of which fines were applied ${ }^{23}$. This decision, however, was criticized by the opposition for restricting freedom of speech. The RA ombudsman appealed it to the Constitutional court indicating the lack of clarity in definitions ${ }^{24}$.

Communication representatives of both RA and RoA Defense Ministries, as well as political leaders, were actively using social media as their main communication channels. The main information sources were the representative of the Defense Ministry of RA Artsrun Hovhannisyan and spokesperson Shushan Stepanyan who conducted communications through their personal pages.

Meanwhile, the Internet Freedom Index classifies Azerbaijan as a not-free country $^{25}$. Before starting military actions Azerbaijan had banned social media sites, except Twitter. Only media and state structures had Internet access ${ }^{26}$. President Aliyev and other officials were actively using Twitter to promote state propaganda and theses. Some researchers assume that this platform was suitable for the regime for organizing propaganda campaigns and controlling the flow of information $^{27}$. No wonder that under such an authoritarian approach the most popular downloaded applications and Google searches in the country referred to VPN tools with the help of which some part of society still could have access to banned websites and social media platforms ${ }^{28}$.

The Azerbaijani side did not provide information about its human losses, instead publishing fake lists of Armenian victims taken from the electoral register ${ }^{29}$.

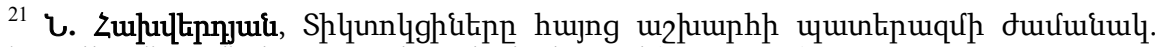
URL: https://media.am/hy/newsroom/2020/10/01/24384/ (27.04.2021).

22 Zujunupunnıpjnı\{. URL: https://www.sns.am/hy/... (27.04.2021).

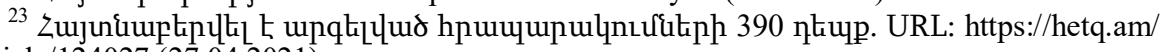
hy/article/124027 (27.04.2021).

${ }_{25}^{24}$ URL: https://www.facebook.com/permalink.php?story_fbid... (27.04.2021).

25 Freedom on the net 202. Azerbaijan. URL: https://freedomhouse.org/country/ azerbaijan/freedom-net/2020 (27.04.2021).

${ }^{26}$ Country-wide internet disruptions reported in Azerbaijan [updated]. URL: https://www. az-netwatch.org/news/country-wide-internet-disruptions-reported-in-azerbaijan... (27.04.2021).

${ }^{27}$ Pearce K. While Armenia and Azerbaijan fought over Nagorno-Karabakh, their citizens battled on social media. URL: https://www.washingtonpost.com/politics/2020/12/04/while-armeniaazerbaijan-fought-over-nagorno-karabakh-their-citizens-battled-social-media/ (27.04.2021).

28 Mobile App Ranking: Azerbaijan. URL: https://www.similarweb.com/apps/trends/ apple/store-rank/az/all/top-free/iPhone/ (27.04.2021).

${ }^{29}$ URL: https://www.facebook.com/samvel/posts/10158743445218781 (27.04.2021). 
The Armenian side, on the other hand, used this opportunity and took the role of information provider on human losses, publishing lists of dead Azerbaijani soldiers on social media. A special Telegram account was created for this purpose ${ }^{30}$. Activities of international media representatives were also under Azerbaijani state control in order to manage the foreign media coverage of the war. It is noteworthy that the same communication strategy was implemented during April 2016 ${ }^{31}$, when journalists were reporting about constant control over their actions and movements ${ }^{32}$. Such practices are strictly linked to the media framing strategy employed by the authoritarian regime of Aliyev, which supports the general media coverage of the Nagorno-Karabakh conflict mostly oriented towards confrontation. As Atanesyan notes, countries like Azerbaijan, with unfree media and Internet and imprisoned journalists, hinder chances for alternative media coverage of the conflict, in particular, framing, based on peace journalism ${ }^{33}$.

\section{Research methodology and questions}

Critical Discourse Analyses (CDA) is a multidisciplinary approach originating from critical theory (Gramsci, Althusser and the Frankfurt school), critical linguistic theory, and Michel Foucault's discourse theory ${ }^{34}$. The primary goal of CDA is to analyze the two-way relationship between language and the social: how language is socially shaped and how it constitutes it. CDA aims to explore the relationships of causality and determination between discursive practices, events, text, and wider socio-cultural structures, relations and processes, in particular, ideology and power ${ }^{35}$. Emphasizing the relationship between language and power, Wodak and Meyer define the main goal of CDA to critically investigate social inequality, as it is expressed, signaled, constituted, legitimized or so on, by the language or discourse. In this regard, discourse is acknowledged as an agent contributing to power relations in a society ${ }^{36}$. The discourse historical approach, developed by them, aims to analyze the social, political and historical background related to the discursive events integrating available knowledge and social theories37. CDA is a problem, not a theory-driven framework, addressing analyses of language use to show "strategies of manipulation, le-

${ }^{30}$ URL: https://t.me/war_front?fbclid... (27.04.2021).

31 Forestier-Walker R. Nagorno-Karabakh: Who Won the Media War? URL: https://eurasianet.org/nagorno-karabakh-who-won-the-media-war (27.04.2021).

${ }^{32}$ Ghazanchyan S. France 24 reporter says Azerbaijan controls journalists' movements and freedom to report. URL: https://en.armradio.am/2020/10/12/france-24-reporter-says-azerbaijancontrols-journalists-movements-and-freedom-to-report/ (27.04.2021).

33 Atanesyan A. Media Framing on Armed Conflicts: Limits of Peace Journalism on the Nagorno-Karabakh Conflict // Journal of Intervention and Statebuilding, 2020, DOI: 10.1080/17502977.2020.1780018

${ }^{34}$ Foucault M. Power/knowledge: Selected interviews and other writings. New York: Pantheon, 1980 .

${ }^{35}$ Fairclough N. Critical discourse analyses and the marketization of public discourse: the universities, 1993, p. 134-135. DOI: https://doi.org/10.1177/0957926593004002002 (27.04.2021).

${ }^{36}$ Wodak P.R., Meyer M. Methods of Critical Discourse Analysis. SAGE Publications, London, 2001, p. 11-37

${ }^{37}$ Ibid, p. 66 
gitimation the manufacture of consent, and other discursive ways to influence the minds (and indirectly the actions) of people in the interests of the powerful38. Van Dijk focuses on the examination of ideologies as basic systems of beliefs and suggests the "ideological square" for analyzing different levels of discourse structures and reflections of ideologies through meanings ${ }^{39}$. He considers discourse not just as text, but a form of interaction. A full account of news discourse, then, requires both a description of textual structures of news and a description of the production and reception processes of news discourse in communicative situations and socio-cultural contexts ${ }^{40}$. According to Jager, the main purpose of CDA is the examination of the way discourses exercise power with all its effects and how it forms public consciousness. "Discourses exercise power as they transport knowledge on which the collective and individual consciousness feeds. This emerging knowledge is the basis of individual and collective action and the formative action that shapes reality". ${ }^{41}$

Discursive practices in emerging digital contexts are multimodal and combine textual, oral, visual forms of narratives. Androutsopoulos's approach of Discourse-Centered Online Ethnography (DCOE) focuses on the relationships and processes taking place online and combines virtual ethnography with sociolinguistics ${ }^{42}$. The "Computer-Mediated Discourse Analyses" approach, developed by Herring, refers to any analysis of online behavior that is grounded in empirical, textual observations, applying the following levels of analyses: structure, meaning, interaction and social behavior ${ }^{43}$. She also takes into consideration the technological features of online platforms and their effects on digital communication. Eisenlauer went further, analyzing the role of the hypertextual structure of online platforms, selective nature of the information flow, determined by algorithms, as well as how software services give shape and coherence to users' text creation and processing practices by providing them text generation and distribution tools ${ }^{44}$. Fairclough draws attention to the historical shift of global discursive practices, in particular, colonization of the discourse by promotion, its marketization and technologization determined by characteristics of modern consumerist and post-traditional societies ${ }^{45}$. pp. $17-27$

${ }^{38}$ Van Dijk T. A. The Aims of Critical Discourse Analysis', Japanese Discourse, 1: 1995, ${ }^{39}$ Van Dijk T. A. Ideology and discourse. A Multidisciplinary Introduction, SAGE Publications Ltd, London, 2000, p. 44.

${ }^{40}$ Van Dijk T. A. News As Discourse, Lawrence Erlbaum Associates, Inc, 1988, p. 37 -38.

${ }^{41}$ Wodak P.R., Meyer M. Methods of Critical Discourse Analysis. SAGE Publications, London, 2001.

${ }_{42}$ Androutsopoulos J. Potentials and limitations of discourse-centred online ethnography. Language@Internet 5(8), 2008.

${ }_{43}$ Herring S. C. Computer-Mediated Discourse Analysis An Approach to Researching Online Behavior, Cambridge University Press, 2004, p. 2.

${ }^{44}$ Eisenlauer V. A Critical Hypertext Analysis of Social Media_ The True Colors of Facebook, Bloomsbury Academic, 2015, p. 96.

${ }^{45}$ Moberg M. Mediatization and the technologization of discourse: Exploring official discourse on the Internet and information and communications technology within the Evangelical Lutheran Church of Finland. New media \& society, 2018, Vol. 20(2), pp 515-531. 
The methodological framework of this research is constituted by the CDA method, in order to reveal discursive tactics, rhetoric devices, ideological and meaning structures applied within the framing of the Nagorno-Karabakh War in 2020. Distinctly, this study aims to answer the following research questions:

1. What ideological and mythical constructs are used to frame the war discourse?

2. What are the main rhetorical and argumentation devices applied?

3. How does war framing represent the images of "us" and "them"?

4. How are the frames linked to broader social and historical context?

5. What does the framing keep silent about?

6. How did social media influence the war framing?

The sample is chosen purposefully, including Artsrun Hovhannisyan's Facebook posts published during the war period - September 27-November 10. Although Hovhannisyan carried the war communications on multiple social media platforms (Facebook, Instagram, Telegram, and Twitter), the content on these platforms was mainly repetitive. The key communication channel was Facebook, as it was the most popular social media in Armenia (1 689000 users, $57.6 \%$ of the entire population, as of September 2020) ${ }^{46}$. Thereby, in the frames of this research, only Facebook posts have been analyzed. Overall, Hovhannisyan made 612 posts during the war period, 432 of which were original and 181 - shared from other pages or websites ${ }^{47}$. He shared posts from various sources, including official pages of the Armenian or Artsakh state bodies or their representatives (most frequently, Shushan Stepanyan's page), as well as ordinary users. Because the main target audience was the Armenian society, the main language of the posts was Armenian, although some posts, in particular, official announcements, were also in English and Russian. The majority of the posts were textual (65\%), the other part equally contained photos or videos.

As a result of the analyses, a few generic frames have been revealed and are discussed in the next part of the paper.

\section{"Trustworthy news source" frame}

During armed conflicts, when both the present and the future are highly uncertain, trust is needed to reduce complexity. As Luhmann notes, "In trusting one engages in action as though there were only certain possibilities in the future ${ }^{48 \text { ". }}$ Considering the diversity and availability of multiple information sources on the web, one of the key purposes for the war framing was gaining public trust towards the official sources. In this regard, the discourse within official posts reflects a remarkable effort to draw a line between "us" and "them" as "untrustworthy" and "the only trustworthy" sources. Two discursive practices were used

46 Facebook users in Armenia. URL: https://napoleoncat.com/stats/facebook-users-inarmenia/2020/09 (27.04.2021).

${ }^{47} 607$ posts were analyzed, as the content of 5 posts was no longer available at the moment of analysis.

${ }^{48}$ Luhmann N. Trust and Power, John Wiley \& Sons Inc., 1982, p. 20. 
for this aim: portraying the Azerbaijani side as a fake news spreader and Hovhannisyan - as the only one who was authorized to provide information on the war:

"Those who think they are more authorized to inform society about the front should think: you can also report the location of the new weaponry and details on actions. This can be useful for the enemy. Report it, too, that's all ${ }^{49}$ ".

Meanwhile, the fake character of the information spread by the Azerbaijani side is presented as a given fact:

"Now they will deny our army's success. That's normal. In Apsheron they don't like bad news, and they can't bother the Sultan with bad news. That's ok, the facts will arrive. \#Wewillwin ${ }^{50, "}$.

Nevertheless, calls to avoid following or spreading Azerbaijani sources were inevitable. These calls found support among the internal audience that even urged to apply stricter measures for people ignoring them, because, as a user mentioned in a comment: "The society has given him (Hovhannisyan) that right ${ }^{51}$ ".

It is noteworthy that the Azerbaijani state strategy of spreading fake content was successfully supporting this framing. On October 8 Facebook announced the removal of a network that originated in Azerbaijan, including 589 Facebook accounts, 7,906 Pages and 447 accounts on Instagram that were involved in coordinated inauthentic behavior. These networks used fake pages in order to boost state propaganda through commenting ${ }^{52}$. In this regard, we can state that tech companies like Facebook, which provide a platform and tools for informational warfare operations and control blocking pages and users, can also be considered as subjects of modern informational wars.

The everyday language style of the messages can be analyzed as a particular framing technique. It portrayed Hovhannisyan not as much as the official representative of the Ministry of Defense, but "a guy from the next door", who is always genuine and speaks the truth. Although everyday language style corresponds with the logic of content creation on social media, it is still not that common within state communications practices during armed conflicts. In this sense, special attention deserve non-standard words used to frame military operations, which became memes and went viral. One of such words was "zgetnel" (to hit), used to describe the beating of Azerbaijani drones and other air weaponry. Another viral meme was "Gyorbagyor2020" (without grave), introduced to be used in context of battles in Shushi.

\section{Framing through hashtags}

In general, the war discourse was actively framed through hashtags, both in English and Armenian, circulating on social media platforms and promoting

\footnotetext{
${ }^{49}$ URL: https://www.facebook.com/arcrun/posts/3492857034083213 (27.04.2021).

${ }^{50}$ URL: https://www.facebook.com/arcrun/posts/3413098055392445 (27.04.2021).

${ }^{51}$ URL: https://www.facebook.com/arcrun/posts/3492857034083213 (27.04.2021).

52 Gleicher N. Removing Coordinated Inauthentic Behavior. https://about.fb.com/news/ 2020/10/removing-coordinated-inauthentic-behavior-september-report/ (27.04.2021).
} 
key official theses or confronting the Azerbaijani ones (e.g. "\#ArtsakhStrong, \#RecognizeArtsakh, \#NkPeace, etc.). However, the key hashtag was the slogan of the war - "We will in", introduced on the very first hours of the war by Hovhannisyan. The hashtag quickly went viral and became the most popular textual meme of the war, used not only in textual but also in visual communications, both online and offline. The hashtag was posted 109 times on Hovhannisyan's page, 16 of which do not contain any other message. There are more than 222000 posts with the hashtag on Facebook (as of 16.03.21). It is notable that even in offline communications, including outdoor banners and even clothes for sale, the slogan was written with the hashtag sign. Although this article does not aim to analyze the audience's feedback, some of the comments are worth mentioning in the scope of the slogan repetition effect as a framing mechanism. Some of the comments on his posts show that the fact of victory was perceived as something that already had happened and each hashtag was grasped as implicit proof of successes of the Armenian army or the final victory. Examination of the comments sheds some light on such perceptions among the audience: it does not doubt the truthfulness of messages, but instead, demands details for a fact it already knows. Too much trust over the victorious future transformed it into a present or even past event.

"We know, /that we have won/ but please, write a little more detailed" ${ }^{53}$ ",

"Is it only me thinking that each \#haghteluenk written by Artsrun is a hidden message about lots of corpses of the sheep $?^{54}$ ".

Although the slogan, due to its simplicity and attractiveness, went viral, in sense of meaning it was still vague and unclear. The conflict and the military situation themselves were historically and politically too complex to provide a universal definition of victory. Meanwhile, neither there was an official commonplace definition of the victory, nor a public consensus regarding it: did "We will win" mean occupying new Azerbaijani territories, reaching Baku or resuming the status quo as of September 27? In fact, the Armenian nation was united around a purpose for which its various groups did not have a common interpretation. This means that even a more favorable outcome for Armenia in the conflict might cause polarizing postwar discussions and risk the shaky national unity anyway.

\section{"Victory argumentation" frame}

Critical role in the war discourse played the framing of the victory argumentation, aimed to sow hope and belief towards the final victory. The potential victory was often declared as an inevitable event, which was quite suitable with the main slogan "We will win".

"There is no other way. This is a war of survival and we are fated to $\mathrm{win}^{55 \text { ". }}$

\footnotetext{
${ }^{53}$ URL: https://www.facebook.com/arcrun/posts/3411796012189316 (27.04.2021).

${ }^{54}$ URL: https://www.facebook.com/arcrun/posts/3411796012189316 (27.04.2021).

${ }^{55}$ URL: https://www.facebook.com/arcrun/posts/3465271626841754 (27.04.2021).
} 
Nonetheless, a few posts draw argumentations for the victory by employing certain discursive strategies. The main factors contributing to the future victory are the following: the will and intelligence of Armenians; unity of the nation; participation of women in the war; heroes and legends of previous and present wars; the fact that the first war was also heavy, but Armenians managed to win anyway.

"Retreat is not a defeat. There was a retreat in 1918, there was a retreat in 1941, there was a retreat in 1992, but in all those cases there was a victory in the end. There will be another victory. \#Wewillwin ${ }^{56 "}$.

"\#Wewillwin

As this is a holy land, as we don't have a space for retreat, as there are queues of volunteers, as the sons of ministers are joining the volunteers. Proud of You, ARMENIAN NATION ${ }^{57,}$.

However, the key precondition of the victory is the factor of will. Historical references and comparisons were used to highlight its importance:

"It is easy to love Tigran the Great, it is more difficult to understand and love Ashot Yerkat. He got the name Iron for his metal will, for his will to fight alone till the end ${ }^{58}$.

"During the Nagorno-Karabakh conflict in 1991-1994, that lasted about 1,000 days, the Armenian side had difficult, difficult, even seemingly unreliable periods. Moreover, we had some panic moments, but in any case, we were able to overcome it and reach the May 1994 ceasefire, which gave the Armenian diplomacy a strong position in the negotiation process. In autumn, 1992, we could lose Lachin, and not only it, but we managed to stand and win ${ }^{59}$ ".

In these messages a typical argumentation technique is a fallacy, showing faulty relations between premises and conclusions: if we won then, then we will win this time as well. The fact that historical, social, political, and military contexts have changed essentially during a few decades or, moreover, centuries, remains silenced.

The factor of the will gained so much importance that even military power was primarily subordinated to it:

"Smerch, Lauren, Drone - all modern weapons are extremely important. I have written about them for years, justifying the importance of the fifthgeneration war, etc., but will is the key factor, the factor of the will, if you do not want to lose, you do not lose. \#Wewillwin ${ }^{\prime \prime 60}$.

A key aspect throughout the victory argumentation is it's responsible: each and every Armenian is considered as responsible for the victory, thus, becoming from a passive object to a subject and participant of the war.

"Today also I will ask you, Armenian young man: what did you do today to

\footnotetext{
${ }^{56}$ URL: https://www.facebook.com/arcrun/posts/3450722801629970 (27.04.2021).

${ }_{57}^{57}$ URL: https://www.facebook.com/arcrun/posts/3388076877894563 (27.04.2021).

${ }^{58}$ URL: https://www.facebook.com/arcrun/posts/3445904625445121 (27.04.2021).

${ }^{59}$ URL: https://www.facebook.com/arcrun/posts/3434860793216171 (27.04.2021).

${ }^{60}$ URL: https://www.facebook.com/arcrun/posts/3439743942727856 (27.04.2021).
} 
throw the opponent back so that we will win and expel them from our holy land? ${ }^{61}$ ",

However, such subjectification of citizens was quite declarative: people were responsible for the war but they were alienated from the decision-making process, as the events on the last day of the war demonstrated.

During the last days of the war, when heavy battles were going on near Shushi, in order to suppress discussions among the public, trust and belief towards the army were highlighted as the main precondition of victory.

"The army needs our trust. First let's believe in our army, let's believe to $\operatorname{win}^{62, "}$.

Remarkably, such demilitarized framing of the victory discourse significantly contradicts the dramatic portrayial of the war. Through dramatization, the toughness of the war, as well as its importance on the regional and global level were stressed. The war was compared with the $5^{\text {th }}$ generation wars and portrayed as a war of survival: "This heavy war of our survival", "This is not an ordinary war". Direct involvement of Turkey in military actions, drew comparisons with one-century old historical events as well.

"\#WEWILLWIN

In fact, there is no Azerbaijani army, there is a Turkish-Azerbaijani army, which is carrying out an attack on the day of Turkish-Armenian war in 192063".

\section{"Us and them" frame}

A few techniques, which constitute the images of "us" and "them", were revealed in frames of the CDA method. Characteristics of "us" were the following: determination, good knowledge of the territory, courage, patriotism, invincibility, ingenuity, diligence, humility, correct and virtuoso, flawless shooters, brilliant fighters. Meanwhile, Azerbaijani side was portrayed as: bad fighters, coward, savage, disrespectful towards own soldiers, ungrateful, stupid.

The dramatization was used while emphasizing "our" advantages and "their" losses: "You will find inglorious death in the valleys", "Welcome to hell", "History is made each minute", "Amazing heroism and bravery".

Historical reference and comparison with the first Nagorno-Karabakh war were also employed to glorify "us".

"The participants of the 1st Nagorno-Karabakh conflict should know that their sons and grandsons not only continue their work with glory but exceed it multiple times ${ }^{64}$ ".

Illustrations of heroism examples and stories from the frontline, in textual, photo, and video forms, were an important part of "us" glorification. The videos from the frontline soldiers of different ages and speaking in various dialects are presented, thus demonstrating the nationwide unity of Armenians. These stories,

${ }^{61}$ URL: https://www.facebook.com/arcrun/posts/3447594305276153 (27.04.2021).

${ }^{62}$ URL: https://www.facebook.com/arcrun/posts/3499027226799527 (27.04.2021).

${ }^{63}$ URL: https://www.facebook.com/arcrun/posts/3382928681742716 (27.04.2021).

${ }^{64}$ URL: https://www.facebook.com/arcrun/posts/3431379206897663 (27.04.2021). 
mainly exposing heroic actions by individual soldiers, once again reproduce the myth of the advantage of one Armenian soldier over numerous enemies.

"A fact: the picture shows the Akori village or what has remained from the village today on the slope of Ararat... In 481, in Akori village, the Armenian army of 400 defeated the enemy's army of 7000, even though at the beginning of the battle, 100 of our 400 crossed over to the enemy side... These are just the facts that give a clear conclusion and prove that our ARMY cannot be defeated, so it obliged to WIN ${ }^{65}$,".

"Them" portraying was often accomplished with visual framing - photos and videos of beaten Azerbaijani weaponry and dead or running soldier, through which the reality was shaped through local victories. Special attention deserve videos from the frontline, in which soldiers replicate official messages, assuring that victory is "ours".

One of the beloved rhetorical devices employed by Hovhannisyan within "us and them" framing was sarcasm and irony. The Azerbaijani state or military leaders and army were often mocked and portrayed as weak and incompetent.

"Azerbaijani propaganda is passive about the "victorious" success of their army. Has anything happened?? Haven't they "liberated" new continents? How can it be? Is there probably a gap between the planning and implementation of the operation and the information support? ${ }^{66}$ ",.

"It seems like the General Staff of the Azerbaijani Armed Forces has deceived Ilyush again and reported a wrong map to him $^{67, "}$.

As the posts above demonstrate, the naming of the Azerbaijani leaders is also made in a rather sarcastic manner. In a few posts, Azerbaijani president Ilham Aliyev is called "Ilyush", which is the diminutive form of the name Ilham in Russian. Meanwhile, Aliyev's wife, Mehriban Aliyeva, got the name "Land kisser", which refers to her statements on a wish to kiss the land in Artsakh. Hence, the enemy was also portrayed in a rather personified manner.

"Somebody tell Ilyush why doesn't he visit Mataghis, and yes, he can take that land kisser with him h8", $^{6}$

Metaphors and comparisons were frequently used as discursive techniques throughout the war framing. "Us" framing was employed through comparisons of Armenian soldiers with a "suddenly awakened tiger", "eagles (of mountains)", "lions". Meanwhile, the enemy was compared with "hyena", "sheep", "reptile", "cattle". Sanctification and deification of Armenian soldiers is also worth to be noted ("Holy Martyrs", "Our artillerists are gods", "World's first crusaders, torchbearers of civilization"). The enemy, on the other hand, was described as "bandits" and "genocide makers".

In general, the mythicized war discourse, circulating since the war in 2016 ,

${ }^{65}$ URL: https://www.facebook.com/arcrun/posts/3501508366551413 (27.04.2021).
${ }^{66}$ URL: https://www.facebook.com/arcrun/posts/3382486951786889 (27.04.2021).
${ }^{67}$ URL: https://www.facebook.com/arcrun/posts/3422427581126159 (27.04.2021).
${ }^{68}$ URL: https://www.facebook.com/arcrun/posts/3402526459782938 (27.04.2021). 
was activated in a more inflated manner, lowering the "us and them" contradiction to primitive "good and evil" language. The representation of the enemy in the light of its weakness and incompetence reflects general stereotypes about the Azerbaijani army and nation, thus, making the declaration of the upcoming victory more credible. Again, the issue of military excellence and objective factors remain ignored in the light of the general superiority of one nation over another. In this regard, the promotion of the enemy's negative image is carried in a rather contradictory way. On the one hand, the Azerbaijani side is portrayed as a collective "Turk", with references to Genocide and terrorists. In parallel with humiliation, the enemy's unserious image was continuously highlighted, thus, excluding any serious danger. This was another replication of discursive practices examined by Zhamakochyan during the four-day war in $2016^{69}$. Such ideological background of the war discourse is not surprising, considering the absence of Armenian national ideology in general. Development of the latter is vital not only in general but also in sense of creating an ideological basement for further military communications.

It is remarkable that following the public discourse, "them" included not only external but also the internal enemy. Armenian users, publishing information contradicting the official propaganda, were labeled as "Turks". Sarcastic rhetoric was also used in this sense, to suppress public discussions on the military situation:

"Super-experts, military professors, masters of "closing the air", be a little discreet $t^{70 " .}$

The engagement of thousands of Armenian in voluntary initiatives, in particular, those regarding informational warfare, was one of the central topics in frames of the nation's glorification discourse. More than 20 voluntary groups were created on Facebook aimed to spread official information through various online channels (Facebook, Twitter, Instagram, LinkedIn, Vkontakte, and YouTube), create content, confront the Azerbaijani propaganda and monitor online platforms. In one of his posts, Hovhannisyan thanked the volunteers for their contribution to the informational war. However, the fact that the state was not properly ready for the informational war, was silenced. The same relates to the posts regarding the Armenian volunteers worldwide working offline to provide supplies for the army and refugees.

The issue of state responsibility was neglected in another post addressing Aliyev's statements, where the latter questions the sources the Armenian army gets its weapons.

"Tell someone that the Armenian people are the ones who arm the Armenian army. \#Wewillwin".

Although the message looks like a response to the Azerbaijani president, in fact, it targets not Aliyev, but rather, the internal audience, aiming to glorify the

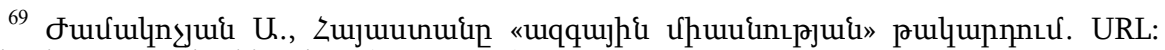
http://socioscope.am/archives/779 (27.04.2021).

${ }^{70}$ URL: https://www.facebook.com/arcrun/posts/3482374348464815 (27.04.2021). 
nation once again. In other respects, the fact that the army supplier is the nation, not the state and its bodies, is silenced by the pride about nationwide unity. In general, glorification of "us" makes its primary object the Armenians as a nation, but not Armenia as a state. The personification of the communication strategy also failed to portray the state as a subject of the war. Although personalized communications might have increased the level of trust towards the state representatives, the absence of the state as a subject did not seem logical in sense of dominant framing around the national unity. At the same time, this contributed to the prevention of questioning the responsibility of the state and its bodies, as it was during the four-day war $^{71}$.

It is notable that during the war there was a series of posts popular among ordinary users, mocking the Armenian nation's bad habits. A comment by a user, made under the news about the fake list of Armenian victims published by the Azerbaijani side, is a good illustration: "They can't imagine that we are a nation that has seen fraudulent election lists. We don't believe in such things ${ }^{72}$." After November 10, the same negative characteristics were circulating through social media platforms by Armenian users in frames of the public discourse "We lost because...". The general perception of national disadvantages as an asset once again proves the high level of euphoric public mood during the war.

\section{Framing through live broadcasting}

Live videos and regular daily updates reporting the military situation at that moment or within a few hours created an effect of live broadcasting of the war. This allowed the audience to follow the situation anytime and from any place, right in front of their computer or smartphone screens. In case of drone or plane losses updates for each single hit equipment of the enemy, especially for drones, were even provided. The topic of drones was mainstream in general public discourse, as this weaponry was perceived as one of the main advantages of the Azerbaijani army. Besides, a part of them was produced in Turkey by a firm owned by Erdogan's son-in-law. In this regard, informing the internal audience about the loss of each drone was crucial and had a strong emotional effect, perceived as a little victory towards both Azerbaijan and Turkey.

"Intense battles are going on at this moment at the southern front ${ }^{73}$ ".

Losses of the Armenian side were generally silenced in these updates. They were only exposed in the context of civilian losses, in order to stress the fact of Azerbaijani war crimes. Using numbers was a typical argumentation technique while reporting the enemy's losses. In some episodes, the official propaganda transformed into counting the enemy's losses throughout successive Facebook posts.

Live broadcasting of the war also included daily morning updates regard-

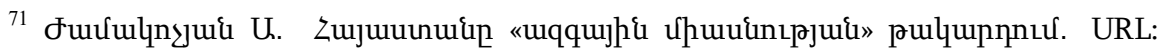
http://socioscope.am/archives/779_(27.04.2021).

${ }^{72}$ URL: https://www.facebook.com/samvel/posts/10158743445218781 (27.04.2021).

${ }^{73}$ URL: https://www.facebook.com/arcrun/posts/3478178642217719 (27.04.2021). 
ing the overall situation. These updates were presented in a rather fuzzy and vague manner, describing the situation as "relatively stable-tense" and masking the losses of the Armenian side: "Defense Army units continue to control the operative situation"; "The losses of Defense Army are being clarified". The actual location of the frontline was also unclear: nothing was said afterward about the result of the ongoing "heavy battles" regarding the frontline. The usual structure of these reports - night fights, the situation in the morning and current situation, was another narrative structuring technique, aimed to draw public mood from anxiety ("heavy battles are going on") to a feeling of safety ("anyway, the situation is under control") ${ }^{74}$. The same technique was employed while putting the hashtag "We will win" at the beginning of the text, describing the overall situation or reporting facts about "our" or "their" losses. Obviously, the war communication strategy was not supposed to reveal all details about the situation in the front, but, in fact, these fuzzy statements could be misinterpreted and mislead the society while figuring out the real situation and boost intolerance towards "bad news". The negative reaction towards journalist Tatul Hakobyan's analyses is a good illustration. On a Facebook post, he stated that Azeris have reached Ishkhanadzor and occupied Jabrail based on the map analyses published by the Ministry of Defense ${ }^{75}$. Although his analysis was logical and correct, many users severely criticized him for spreading fake news and panic. At this point, even logical interpretation of official facts had become an object of public self-censorship.

Overall, live broadcasting of the war created an alternative war reality, excluding sober public opinion. Entman considers frequency as the main powerful framing mechanism ${ }^{76}$. In this regard, Facebook posts, framed with myths and stereotypes, feeding the public consciousness 24 hours a day created an image of reality incompatible with any alternative view. Referring to Baudrillard, the real time broadcasting of the war provides nothing but a useless and empty instant image, and the main function of information becomes covering empty hole of the screen ${ }^{77}$. Social media requires constant update of information, which transforms the aim of war communications from control over public opinion into maintaining communication. Constant flow of national self-glorification and inspirational messages, on the other hand, could cause information overdose for people living under the culture of connectivity. Even Hovhannisyan himself once warned about too much euphoric reactions towards his posts.

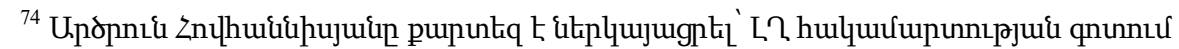
hpurlhชulhh цlipupthpuu. URL: https://www.azatutyun.am/a/30910725.html (27.04.2021).

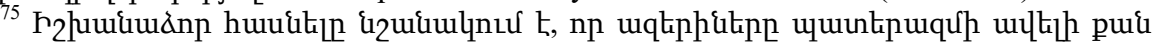

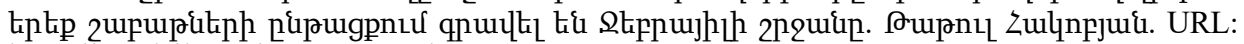
https://armdaily.am/?p=111996\&l=am (27.04.2021).

${ }^{76}$ Bruce M.D. Framing Arab Spring Conflict: A Visual Analysis of Coverage on Five Transnational Arab News Channels, Journal of Middle East Media, Vol 10, Fall 2014, p. 4.

77 Бодрийяр Ж. Войны в заливе не было, РИПОЛ классик, Москва, 2016, р. 23. 
"After yesterday's briefing, once I again noticed unjustified extreme emotions. Everything is not catastrophic, and, moreover, it's not even wonderful. This is a war, we must concentrate all our potential, the struggle is difficult and we must do our best ${ }^{78, "}$.

Again, recalling Baudrillard, we can state that such calls were not enough to distract the public from the "virtual" reality: "our place of obligatory stay is the TV screen, where we are subjected to virtual bombardment on a daily basis, and at the same time act as an exchange value ${ }^{79,}$. On social media the mass selfcommunication multiplies this bombardment effects when the same messages get shared through the networks of the users. The audience, as a passive news consumer, hypnotized by repetitive messages and live updates from the front, could not perceive sober messages any longer. Hence, the media effect for online platforms was much stronger than in case of traditional media, by which messages are delivered in less frequency.

\section{Conclusion}

The objective of this article is to examine war framing during the armed phase in the Karabakh conflict in autumn 2020. The analyses of communication patterns, employing CDA and framing approaches, revealed a few generic frames applied within social media communications: trustworthy news source, victory argumentation, «us» and «them» framing. News frequency, comparisons, stereotyped metaphors, myths were typical techniques used within these frames. The war framing was strongly determined by technological and communication peculiarities of the social media platform on which it was held. Messages were firmly linked to the rules by which these platforms run: personification, creating viral content, e.g. hashtags, humor, and textual memes, and applying everyday language style. However, the media effect of social platforms, requiring updates on 24/7 mode, was not considered properly. In this sense, obeying social media platforms' logic in frames of war communications does not seem relevant, as providing viral and repetitive content makes the act of communication end in itself, constraining the possibility of any meaningful narrative.

Examination of media framing of war applying the CDA method contributes to the implication of this method within digital contexts. Further research is important to broaden the analysis of digital framing practices and their effects on shaping public opinion during armed conflicts.

Keywords: Nagorno-Karabakh conflict, war framing, social media, digital communication, critical discourse analysis

\footnotetext{
${ }^{78}$ URL: https://www.facebook.com/arcrun/posts/3483615358340714_(27.04.2021).

79 Бодрийяр Ж. Войны в заливе не было, РИПОЛ классик, Москва, 2016, p. 16.
} 


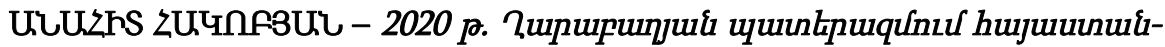

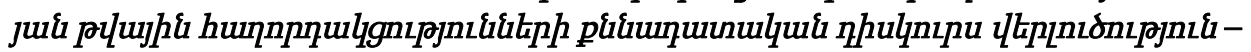

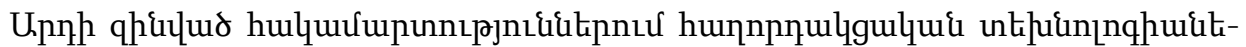

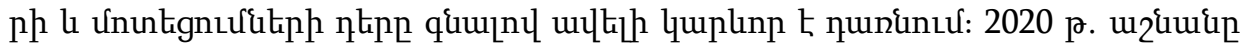

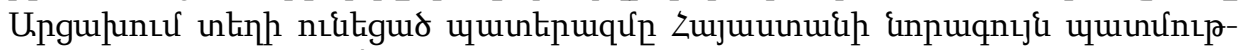

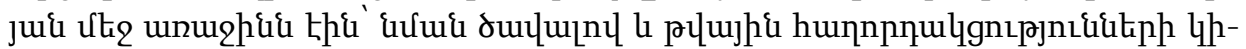

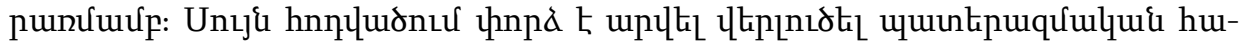

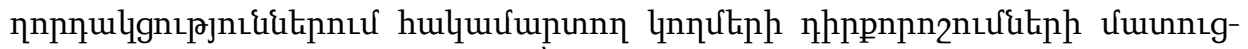

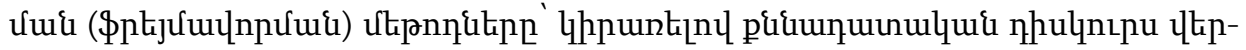

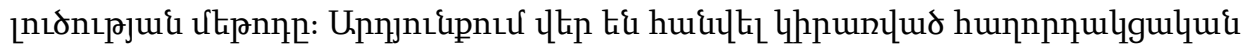

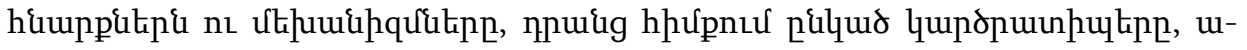

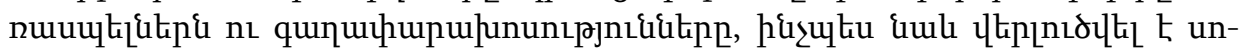

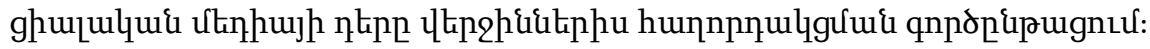

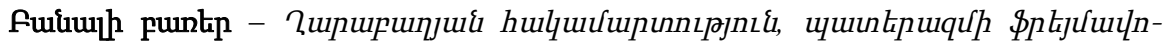

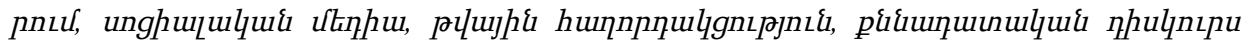

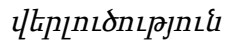

АНАИТ АКОПЯН - Критический дискурс-анализ цифровых коммуникаций Армении в Карабахской войне 2020 года. - Роль медиа и коммуникации в современных военных конфликтах становится все более актуальной. В этой связи Карабахская война 2020 года была знаменательной: это была первая масштабная война в новейшей истории Армении, проходившая в условиях и с применением цифровых коммуникаций. В статье осуществлен критический дискурс-анализ фрейминга войны в цифровых коммуникациях. В результате анализа выявлены приемы и механизмы фрейминга, лежащие в их основе стереотипы, мифы и идеологии, а также роль социальных сетей в цифровых коммуникациях, сопутствовавших военным действиям.

Ключевые слова - Карабахская война, фрейминг войны, сочиальные медиа, ичировая коммуникация, критический дискурс-анализ 


\begin{abstract}
The role of media and communication in modern military conflicts is becoming more and more relevant. In this regard, the Karabakh war of 2020 was significant: it was the first large-scale war in the modern history of Armenia, which took place under the conditions and with the use of digital communications. The article provides a critical discourse analysis of war framing in digital communications. The analysis revealed the techniques and mechanisms of framing, the underlying stereotypes, myths and ideologies, as well as the role of social networks in digital communications that accompanied military operations.
\end{abstract}

Keywords: Nagorno-Karabakh conflict, war framing, social media, digital communication, critical discourse analyses

\title{
About Authors
}

Anahit Hakobyan - Lecturer at Brusov State University, Scientific-Educational center of public communication technologies

E mail: anahit1989@gmail.com

\section{REFERENCES}

Bernays, E. (1923). Crystallising public opinion. New York, NY: IG Publishing Herman, E. S. \& Chomsky N. (2002). Manufacturing consent: The political economy of mass media. New York, NY: Pantheon Book

Lasswell, H. D. (1927). The theory of political propaganda. American Political Science Review, 21(3), 30, 1927, 627-631. Doi: https://doi.org/10.2307/1945515

Browne, H. (2004). The War Racket_The Lies, Myths, and Propaganda That Feed the American War Machine. Nelson Current, 2004, 9-10

Bodriiar, J. (2016). Voiny v zalive ne bylo. RIPOL klassik, Moscow

Welch, D. \& Fox, J. (2012). Justifying War Propaganda, Politics and the Modern Age. Palgrave Macmillan UK, 16. Doi: https://doi.org/10.1057/9780230393295

Libicki, M. C. (2007). Conquest in Cyberspace - National Security and Information Warfare. Cambridge University Press, 34. Doi: https://doi.org/10.7249/CB407

Guenther, L., Ruhrmann, G., Bischoff, J., Penzel, T. \& Weber, A. (2020). Strategic Framing and Social Media Engagement: Analyzing Memes Posted by the German Identitarian Movement on Facebook. Social Media + Society, 6(1), 1-13. Doi:

https://doi.org/10.1177/2056305119898777

Nelson, T., Oxley, Z. \& Clawson, R. (1997). Toward a Psychology of Framing Effects, Political Behavior, 19: 3, 221-46. Doi: https://doi.org/10.1023/A:1024834831093

Atanesyan, A. (2020). Media Framing on Armed Conflicts: Limits of Peace Journalism on the Nagorno-Karabakh Conflict, Journal of Intervention and Statebuilding, 2020. DOI: https://doi.org/10.1080/17502977.2020.1780018

Norris, P., Kern, M. \& Just, M. (2003). Framing Terrorism. The News Media, the Government and the Public. Routledge, 8. Doi: https://doi.org/10.4324/9780203484845 
Evans, M. (2010). Framing international conflicts: Media coverage of fighting in the Middle East, International Journal of Media and Cultural Politics, 6 (2), 209-233. Doi: https://doi.org/10.1386/mcp.6.2.209_1

Makhortykh, M. \& Sydorova, M. (2017). Social media and visual framing of the conflict in Eastern Ukraine, Media, War and Conflict, 10(3), 359-381. Doi: https://doi.org/10.1177/1750635217702539

Iskandaryan, A. (2020). The second Karabakh war, or the first postpost-soviet war, Caucasus Institute, Vienna. Retrived from: https://www.institutfuersicherheit.at/wpcontent/uploads/2020/12/ISP-Working-Paper-Alexander-ISKANDARYAN-The-SecondKarabakh-War-or-the-First-Post-Post-Soviet-War.pdf Atanesyan, A (2013). Hamacancy vorpes LGH azgayin anvtangutyan teghekatvakan pashtpanutyan hartak. 21-rd DAR, No 6 (52), Yerevan, 56

Nazaryan, H. (2017). Adrbejani teghekatvakan qaghaqakanutyuny aprilyan qarorya paterazmum. Banber Yerevani hamalsarani. Mijazgayin haraberutyunner. Qaghaqagitutyun No 1 (22), 54-63

Foucault, M. (1980). Power/knowledge: Selected interviews and other writings. New York: Pantheon

Fairclough, N. (1993). Critical discourse analyses and the marketization of public discourse: the universities, 134-135. DOI: https://doi.org/10.1177/0957926593004002002

Wodak, P.R. \& Meyer M. (2001). Methods of Critical Discourse Analysis. SAGE Publications, London, 11-37. Doi: https://doi.org/10.4135/9780857028020

Van Dijk, T. A. (1995). The Aims of Critical Discourse Analysis', Japanese Discourse, 1. 1727. Doi: https://doi.org/10.1177/0957926595006001001

Van Dijk, T. A. (2000). Ideology and discourse. A Multidisciplinary Introduction, SAGE Publications Ltd, London, 44

Van Dijk, T. A. (1988). News As Discourse, Lawrence Erlbaum Associates, Inc, 37-38

Androutsopoulos, J. (2008). Potentials and limitations of discourse-centred online ethnography. Language@Internet 5(8)

Herring, S. C. (2004). Computer-Mediated Discourse Analysis An Approach to Researching Online Behavior, Cambridge University Press, 2. Doi:

https://doi.org/10.1017/CBO9780511805080.016

Eisenlauer, V. A (2015). Critical Hypertext Analysis of Social Media - The True Colors of Facebook, Bloomsbury Academic, 96

Moberg, M. (2018). Mediatization and the technologization of discourse: Exploring official discourse on the Internet and information and communications technology within the Evangelical Lutheran Church of Finland. New media \& society, Vol. 20(2), 515-531. Doi: https://doi.org/10.1177/1461444816663701

Luhmann, N. (1982). Trust and Power, John Wiley \& Sons Inc., 20

Bruce, M.D. (2014). Framing Arab Spring Conflict: A Visual Analysis of Coverage on Five Transnational Arab News Channels, Journal of Middle East Media, Vol 10, 4. Doi: https://doi.org/10.12816/0023470 